\title{
GODZINA BIBLIJNA W PARAFII SW. TOMASZA AP. W SOSNOWCU
}

Wprowadzone ostatnio w naszej parafii Godziny Biblijne (= GB) odprawiane są głównie w oparciu o sugestie wysuwane przez ks. prof. S. Grzybka oraz ks. prof. W. Smerekę ${ }^{1}$, dodając nowe elementy. W ten sposób program GB kształtował się następująco:

Cz. I - w s tepn a

1. Modlitwa - teksty znane i specjalnie przygotowane.

2. Kursoryczny (10 min.) wykład: Wstęp do Pisma św.

Cz. II - w waściwa Godzina Biblijna

1. Odczytanie kilku wierszy Pisma św. - kolejno przez chętnych uczestników (uzgodnione wcześniej lub: „Kto z Państwa odczyta..." - zawsze znajdą się chętni), stojąco.

2. Omówienie tekstu:

a) tło historyczne,

b) egzegeza filologiczna,

c) zastosowanie teologiczne zakończone krótkim rozważaniem i postanowieniem.

3. Wyjaśnienie zapytań.

Cz. III - koń cow a

1. Komunikaty-ogłoszenia ( $m$. in. zapowiedź nastẹpnego tematu).

2. Tzw. magazyn biblijny - bieżace wycinki prasowe o Piśmie św.

3. Modlitwa końcowa (psalmy czytane lub śpiewane itp.).

4. Wychodzac, uczestnicy składają na tace drobna ofiare na Pismo Św. dla nowożeńców oraz odbieraja nabyte dla nich (przez uprzednie zamówienie) nowe pozycje biblijne i egzemplarze Pisma św.

Podanemu tu dla przejrzystości w punktach programowi należy się bliższe wyjaśnienie.

Jako nowy element GB wprowadzono w cz. I wykład kursoryczny: Wstẹp do Pisma św. Okazało się bowiem, że wierni nasi, przeciętnie biorac, nawet z wyższym wykształceniem, nie pamiętaja lub nie znaja podstawowych niemal wiadomości biblijnych. W naszym wypadku wykazała to ankieta błyskawiczna, przeprowadzona na pierwszym spotkaniu, poświęconym omówieniu znaczenia i sposobom prowadzenia GB. Otóż, na przybyłe wówezas 31 osoby (potem do końca frekwencja ok. $40-50$ osób) tylko jedna odpowiedziala poprawnie na pytanie: ile jest ksiag Pisma św. Starego i Nowego Testamentu, dwie - częściowo poprawnie, podając dobrze liczbę ogólną bez wyszczególnienia, 11 ¡osób odpowiedziało błędnie, podając np. liczbe ksiąg: 2, 12, 15, 21, 24, 28, 40 itd., natomiast 17 osób wstrzymało się od odpowiedzi.

Uczestnicy ogromnie sobie cenią tego rodzaju wykłady, i skwapliwie notują w specjalnie prowadzonym zeszycie. Kazdy wykład posiada zamkniętą dla siebie jednostkę tematyczną, podaną przystępnie, na poziomie szkoły średniej, czasami nieco szczegółowiej, na poziomie wykładu dla alumnów seminarium. Przykład tematyki: nazwy Pisma św., definicja, natchnienie biblijne, jego zakres, natura i skutki, itd. Słuchacze do tego stopnia interesują się, iż niejednokrotnie domagają się skryptu

1 Ks. S. Grzybek: Godzina Biblijna, cz. I. Uwagi metodologiczne, Wiadomości Diecezjalne, nr 6/1959, 213-218.

Ks. Wł. Smereka: Godzina Biblijna i jej znaczenie, Ruch Biblijny i Liturgiczny, nr 1/1960, 1-37. 
z tego zakresu wiadomości. Proszą o wskazanie pozycji dających pogłębienie tego czy innego zagadnienia.

W cz. II, czyli właściwej GB zaczyna się od zapalenia świec, na świeczniku, który stoi na specjalnym podwyższeniu, nakrytym gustownie obok leżącego egzemplarza Nowego Testamentu i ładnych kwiatów. Podwyższenie takie ustawia się $\mathrm{z}$ boku na tle ściany przedniej i bocznej sali katechetyczncj, nazywanej u nas: KAPLICA BIBLIJNA .

Swiece palą sie przez cały czas części drugiẹ. Akcentuje to specyficzność tej części GB o charakterze nabożeństwa, wytwarzając nawet w chwili rozważania nastrój głębokiej zadumy, gdy zgasi się światło elektryczne i widać tylko płonące w półmroku dwie świece.

Czytanie kolejnego odstępu Pisma św. odbywa się stojąco. Czytają chẹtnie uczestniczy GB.

Po przeczytaniu tekstu Pisma św. ten sam kapłan, który prowadzi wykład kursoryczny (w tym wypadku niżej podpisany), przystępując do omówienia tła historyczno-geograficznego i egzegezy filologicznej danego odsteppu. Natomiast drugi kapłan, starszy, bardziej doświadczony przeprowadza zastosowanie teologiczne, udzielajac zebranym i sobie wskazań duchowych, ujętych w jedne, ale realne do przeprowadzenia postanowienie. Pamiętajac o tym, że GB ma dać zebranym przeżycie religijne, w punkcie a i b podaje się tylko niezbędne wyjaśnienia zaspokajające ciekawość słuchaczy i przydatne im do rozmów z drugimi, gdy zajdzie potrzeba wyjaśnienia tej czy innej trudności. Pomoca do tego jest znana na ogól literatura biblijna głównie G. R i c ci ottiego Życie Jezusa Chrystusa ${ }^{2}$.

Jaka była tematyka BG? Ulegając sugestii teoretyków GB, zachęceni posiadaniem IV wydania N. T. Ks. E. D a browskiego i Ks. Wł. Szczepańskiego zdecydowaliśmy się na studiowanie Osoby Chrystusa w oparciu o cztery Ewangelie. Po I roku (1961/62) pracy stwierdzamy, że jest to dosyć trudne dla uczestników, nieobeznanych jeszcze dobrze nawet $z$ szukaniem, praktycznie biorac, odpowiednich wierszy u. poszczególnych ewangelistów. Lepiej będzie przeto poznać kolejno Ewangelie, a potem (jeśli da Bóg doczekać, bo diugo to potrwa, jeśli GB jest co dwa tygodnie i w ciagu roku omówiono 16 tematów, do postu i kuszenia włącznie) pozwolić sobie na ujęcie syntetyczne pod katem Osoby Chrystusa. Naturalnie, zostaje jeszcze przecież i Stary Testament, z którego niektóre księgi czy rozdziały ksiag są odpowiednie do pogłębiania $w$ GB a także dalsze księgi Nowego Testamentu.

Biorąc powyższe pod uwage w roku 1962/63 (lepiej tak liczyć z uwagi na przerwę wakacyjną), mając już poznane cztery rozdziały wg Mateusza, zaczynamy GB od rozdziału piątego tegoż ewangelisty. Należy dodać, że w roku 1961/62 GB odbywała się systematycznie z miesięczna przerwa W styczniu (wizyta duszpasterska) i także w okresie Wielkiego Postu (ze względu na rekolekcje i W. Tydzień).

Po p. 2 części II gasi się świece, zapala się elektryczne światło i proponuje się postawienie pytań, jeśli byłyby jakieś niejasności czy trudności. Wyjaśnia się przeważnie po zgłoszeniu wszystkich pytań, czasami uczestnicy próbują wzajemnie sobie odpowiedzieć i trzeba przyznać na ogól dosyć trafnie.

Wyjaśnianie zapytań (dyskusja) jest przejściem do cz. III, końcowej GB. Zapowiada się tu temat następny, podaje aktualne komunikaty itp. Chętnie słuchają uczestnicy tzw. magazynu biblijnego. czyli wycinków prasowych o Piśmie św., nie tylko z poważniejszych czasopism, ale także z tygodników i dzienników lokalnych czy ogólnopolskich.

Uczestnicy GB lubią modlitwę końcową słowami psalmów, czyta się

2 Wyd. Pax, Warszawa 1956. 
zwykle jeden psalm (naturalnie chętni z laikatu, nie kapłan) w pięknym tłumaczeniu Staffa lub śpiewa wspólnie znany psalm z nieszporów czy Magnificat. W tym miejscu zamierzamy w przyszłości stosować także poważną muzykę religijną (skrzypce, taśma magnetofonowa, płyty). Dla niejednego uczestnika GB będzie to miła sposobność zapoznania się z nieznanym utworem muzycznym, nie mówiąc już o uatrakcyjnieniu spotkania biblijnego.

W czasie jednej GB uczestricy byli zafascynowani, gdy mała dziewczynka z kl. IV recytowała z pamięci psalmy i wypowiedziała bez zająknięcia 51 aforyzmów biblijnych ${ }^{3}$, otrzymując $w$ nagrodzie rzessisie oklaski i ,Psalmy". Tego rodzaju atrakcje wpływaja ogromnie zachę.cajaco na słuchaczy i mamy je zamiar kontynuować. W pewnym sensie miło jest wtedy usłyszeć słowa: „A my? - Dlaczego my tak mało tego znamy?" itp.

Wychodzac, jak juz Wspomniano, uczestnicy GB składaja drobne ofiary na Pismo św. dla nowożeńców, którym wręcza siẹ egzemplarz Nowego Testamentu z odpowiednią dedykacja słowną i pisana po ślubie $w$ kościele $^{4}$.

Przed wyjściem odbywa się także nabywanie na własność, kogo stać na to, nowych ksiązek biblijnych lub egzemplarzy Pisma św. dla znajomych czy dzieci do I Komunii św.

Poza tym pragnę zaznaczyć, że Godzina Biblijna odbywa sie u nas co dwa tygodnie, w piątki, od 18-19,30. Nie sposób zmieścić sic z tak bogatym programem w jednej godzinie. Zresztą uczestnicy prosili o to przedłuzenie, tym bardziej, że GB odbywa sie co dwa tygodnie. Czas nie diuży się wcale i chẹtnie siedzieliby nawet dwie godziny.

Miejsce GB jak już wspomniano - to sala katechetyczna, estetycznie urządzona, wygodna, zima dobrze ogrzana, wyposażona w niezbedne akccsoria, $m$. in. tablice, mape Ziemi Świętej, afisze itp.

Frekwencja: pierwsze spotkanie 31 osób, potem coraz więcej, z odchyleniami 40-50. Ilość uczestników wzrasta, zajdzie wkrótce potrzeba utworzenia dwóch grup: młodzieżowej i starszej. Nłodzieżowej tzn. po maturze do lat ok. 40. Przychodza z wyższym, raczej średnim wykształceniem. Pewna ilość osób posiada wykształcenie podstawowe i pracuje fizycznie, niemniej wykazuje nawet daleko idace zaciekawienie Pismem św. Chętnie takich widzimy, nie chcąc zamykać się $W$ clitarnym getcie.

Prace w ramach GB nie ograniczały się tylko do spotkań biblinych. Uczestnicy chętnie pomagali innym w domowym czytaniu Pisma sw., zachęcali do nabycia Nowego Testamentu. W ciagu roku rozprowadzono 402 egzemplarze Pisma św. i Psalmów. Jest wielkie zapotrzebowanie na Stary Testament, którego nie możemy nigdzie dostać. Udostępniono róvnież pewną ilość przystępnych pozycji biblijnych, jak np. Claudela: Umiłowanie Pisma św. czy ,Znak" 85-86 poświęcony sprawom biblijnym.

Oddziaływuje się także przez gablotkẹ biblijną w przedsionku kościoła i zamieszczone w niej hasła. Zachęcało się do udziału w konkursach, jeśli byly otwierane w czasopismach, np. konkurs zamieszczony w 42 numerze „Gościa Niedzielnego", dotyczący Ewangelii św. Eukasza i inne. W przy-

3 Zaczerpnietych ze skorowidza, umieszczonego $w$ wydaniach ks. E. Dąbrowskiego.

4 Dedykacja pisana: Państwu (X, Y) W JASNYM DNIU ŚLUBU z najlepszymi życzeniami i pragnieniami, by życie małżeńsko-rodzinne oparli na Ewangelii - Tej „Najpiękniejszej Księdze Świata” (podpis proboszcza i księdza błogosławiącego związek małżeński, Parafia św. Tomasza Ap. w Sosnoweu, data). 
szłości mamy zamiar od czasu do czasu zainicjować własny konkurs biblijny, najbliżsy przeprowadzony został w TYGODNIU BIBLIJNYM od 24-30 września 1962 roku.

W wyniku akcji popularyzacyjnej nabywano dzieciom przystępujacym do I Komunii św. różne wydania Nowego Testamentu — od zwykłego (po $25 \mathrm{zh}$ ) do ozdobnego (po $150 \mathrm{zl).} \mathrm{Obecnie} \mathrm{dzieci} \mathrm{te,} \mathrm{prawie} \mathrm{wszystkie,}$ przynosza na lekcje Ewangelie, co stanowi wielką pomoc dla katechetów w nauczaniu. Dzieci w domu przygotowują się z Pisma św., wynotowuja zeń wskazane słowa, ucza się na pamięć teksitów itd.

Prowadzi się wreszcie dla dokumentacji kronikę GB, księgę korespondencji, ogłoszeń i archiwum.

Sosnowiec, wrzesień 1962

KS. WACEAW CHMIELARSKI

\section{O. Franciszek Malaczynski OSB, Tyniec}

\section{USTANOWIENIE PATRONOW POLSKI}

Kodeks rubryk postanawia, że każdy naród, prowincja lub diecezja może mieć jednego lub dwóch patronów głównych oraz najwyżej dwóch patronów drugorzędnych. Patronami moga być tylko Ŝwięci a nie Błogosławieni. W ostatnich wydaniach Proprium Poloniae jako głowny patron. Polski jest wymieniony św. Stanisław, Biskup krakowski i Mieczennik. Przy badaniu dawnych tekstów liturgicznych stwierdza się jednak, ze był czas w którym św. Wojeiech, Biskup i Męczennik byl czezony na równj. ze św. Stanisławem. Liczne sa ikonograficzne pomniki takiego kultu obydwu patronów. Ponadto wielu innych Swiętych a nawet Blogosławionych zostalo zaliczonych inter primarios Regni Polonide Patronos.

W ostatnich wiekach główne miejsce w pobożności narodu polskiego zajęła Matka Bó̇a. Od ślubów Jana Kazimierza odbierała Ona kult jako Królowa Polski, ale nigdy nie została formalnie ustanowiona patronka Polski i dlatego Jej święto nie miało praw liturgicznych przysługujących świętom patronów. W związku z opracowywaniem nowego Proprium Poloniae wypadało uporząlkować te sprawy i uzgodnić kult liturgiczny z pobożnością narođu. Dlatego J. Em. Ksiądz Kardynai Prymas w imieniu Konferencji Plenarnej Episkopatu wnióst do Stolicy Apostolskiej prośbe o ustanowienie główną patronką Polski Najświętszej Maryi Panny pod wezwaniem Królowej Polski, a patronami równorzędnymi świętych Biskupów i Męczenników Wojciecha i Stanisława. Równocześnie prosił o zatwierdzenie jako patrona drugorzędnego św. Stanisława Kostki Wyznawcy. Ponieważ Kodeks rubryk przewiduje możliwość ustanowienia najwyżej dwóch patronów głównych, prośba biskupów Polski była prośbą o przywilej. Ojciec święty Jan XXIII przychylił się jednak do tej prośby i dnia 31 sierpnia 1962 ustanowił trzech równorzędnych głównych patronów Polski: Najświętszą Maryję Pannę pod wezwaniem Królowej Polski, św. Wojciccha, Biskupa i Męczennika oraz św. Stanisława, Biskupa i Męczennika oraz zatwierdził św. Stanisława Kostke jako patrona drugorzędnego. Wobec tego w całej Polsce należy obchodzić ich uroczystości jako święta 1 klasy. Obowiąują one także zakonników mających własny kalenđarz. Uroczystość św. Stanisława Kostki otrzymuje 2 klasę w całej Polsce. Zakonnicy nie muszą jednak obchodzić tego święta. Prawdopodobnie po raz pierwszy użyto w dekrecie papieskim imienia „Wojciech" w brzmieniu używanym w Polsce. 